\title{
(Re-)telling stories: narrative theory and the practice of client counselling
}

\author{
Dr Paul Maharg
}

\begin{abstract}
The field of narrative studies is currently influencing methodology in many areas of research and learning in the arts and social sciences - historiography, psychology, philosophy, theology, therapy and education amongst others. Researchers in these domains have used narrative theory to help them examine how narratives concerning professionals are constructed, and what this tells us of the professionals themselves, their view of their profession, their place within it, and their relations with clients. Most of these studies emphasise the teleological role that narrative inquiry can play in providing individuals with the opportunities to achieve new understandings about the nature and process of practice and the communities within such practice is enacted.

This article describes the application of aspects of narrative theory to legal education. It describes the use to which narrative criticism was put in a third level module on clinical legal skills at Glasgow Caledonian University. Some key concepts in narrative theory were used in class discussion of videotaped client counselling interviews between solicitors and clients. The narrative concepts were also reinforced in other areas of the module dealing with negotiation and writing skills. Through the discussion of the videotapes and reflective practice using recipes, students came to a deeper appreciation of the experience of one important aspect of legal practice.
\end{abstract}

[T] he study of narrative, like the study of other significant human creations, has taken a quantum leap in the modern era. No longer the province of literary specialists who borrow their terms from psychology and linguistics, the study of narrative has become an invaluable source of insight for all the branches of human and natural science'.

Why is there such a rush to storytelling? Why has narrative become such an important and recurring theme in legal scholarship these days?

It is with this question that the editor Kim Lane Scheppele opened the Foreword to a special issue in 1989 of the Michigan Law Review on the place of narrative in legal discourse. Throughout the eighties and especially in America there was a steady growth in the number of articles and books concerned with law and narrative; and in the nineties there has been no slackening of interest: narrative and especially narrative theory remains a recurring interest for lawyers. There are two clear strands to the research. First, the law and literature movement has used narrative theory to analyse the relations between literature and law, and to critique the place of law in society. Second, those involved in 'critical lawyering', clinical skills, and the ethnography of legal discourse have employed narrative theory teleologically in order to open up new 
understandings of the operation of law practice and legal education. ${ }^{3}$ As Scheppele points out, 'narrative is a way of organising, coping with, even acting on the world'. As a result the substantial bodies of theory which seek to explain how narrative operates are powerful tools for enabling understanding in any particular discipline.

In the first section of this article I will describe some key aspects of narrative theory relevant to legal client counselling. The second section will illustrate some uses to which the study of narrative has been put in a variety of disciplines; and then examine the place of narrative theory in the research literature dealing with client counselling. In the third section, I describe how narrative criticism was embedded and used within a level three undergraduate client counselling class. ${ }^{5}$

\section{Reader-response and point of view}

The variety of critical approaches to narrative is vast; but in the heuristics of the client counselling class one approach was employed, that of reader-response theory as it is presented in the work of Wolfgang Iser in particular. Iser's theory of reading explores the reader's engagement with the text, and focuses on issues such as the place of intentionality in the creation and reading of texts, and ways in which readers create and structure meaning from texts. One issue amongst these was particularly relevant to the class, that of 'indeterminacies' within texts. According to Iser, texts are full of gaps or blanks in their structures of meaning, much as there are gaps in conversational dialogues. A reader will respond to a gap by making

his own decision as to how the gap is to be filled. In this very act the dynamics of reading are revealed. By making his decision he implicitly acknowledge the inexhaustibility of the text; at the same time it is this very inexhaustibility that forces him to make his decision. ${ }^{6}$

This decision is rarely fixed: re-readings of the text, changes in the reader's circumstances and readings of the text within new contexts can alter it. As Iser describes it, the process is hermeneutic:

[ $\mathrm{t}]$ he text provokes certain expectations which in turn we project onto the text in such a way that we reduce the polysemantic possibilities to a single interpretation in keeping with the expectations aroused, thus extracting an individual, configurative meaning. ${ }^{7}$

Expectation and interpretation are thus interlinked and constantly acting on each other. In this sense, reading a text is similar to experiencing real life, where ideas are formed by the interaction of anticipation and memory. This process is not a smooth one, though. Gaps and indeterminacies attract us by their quality of interrupting the flow of meaning creation within us. As Iser has it,

[w] look forward, we look back, we decide, we change our decisions, we form expectations, we are shocked by their nonfulfillment, we question, we muse, we accept, we reject: this is the dynamic process of recreation. ${ }^{8}$

Implicit in the reader-response enterprise is the notion of viewpoint and authority. We cannot read a text unless from a point of view, and our situation as reader inevitably affects our sense of the authority of what we read. As Ian Reid put it, 'narratorial authority is always at stake in a storytelling situation, whatever the tactical variations'. 'Our knowledge of the author and his or her previous writings and viewpoints always affects our reading; and if we know little of this, we construct and reconstruct authorial voice and context from textual details. This applies to our 
reading of what we might regard as a functional text such as a memo or legal judgement as well as a literary work such as a novel.

It also applies to the readings of a community of readers. Indeed, it was precisely this difficulty of accounting for differences and similarities in interpretive readings within a community of readers which led another critic, Stanley Fish, to develop his concept of 'interpretive communities' - that is, communities of readers who share practices and ways of communicating meaning. As Fish describes it,

[i]nterpretive communities are no more than sets of institutional practices; and while those practices are continually being transformed by the very work that they do, the transformed practice identifies itself and tells its story in relation to general purposes and goals that have survived and form the basis of a continuity. ${ }^{10}$

As Fish pointed out, we are always in a world where there are constraints 'in the form of imperatives, urgencies and prohibitions that come along with any point of view (and being in a point of view is not something one can avoid)'. Fish gives us a practical example of such situated point of view:

When Judge Parker sits down to consider Mills $v$ Wyman he is in no sense "free" to see the facts in any way he pleases; rather his very first look is informed (constrained) by the ways of thinking that now fill his consciousness as a result of his initiation into the professional community of jurists. ${ }^{11}$

If Iser's concept of indeterminacy contributes to our sense of how meaning is created, Fish's analysis of the concept of the interpretive community contributes to our sense of how that meaning is constrained in practice. As we shall see, these concepts were used in the client counselling class described below to enable students to carry out effectively not only analysis of client counselling but the practice of it as well.

\section{Narrative theory and other disciplines}

Narrative theory has been taken up by disciplines outwith literary theory, and for some time now has been deployed to open up new areas within disciplines. Two example will suffice.

In education, narrative studies has become a powerful tool for the analysis of practitioners' experiences and of teacher education. ${ }^{12}$ For influential researchers such as Elbaz, and Connolly and Clandinin, the professional knowledge of teachers is not static and contextless cognitive knowledge. Rather, it is practical knowledge, instrumental in shaping situations and experiences, and shaped by these also. ${ }^{13}$ This has led to the gradual development of a distinctive educational ethnography, one where the goal of research is to understand and represent the subject's, that is, the practitioner's, experiences and narratives. In this ethnography, information is collected using interviews and observation and dialogue.

This is also the case for lines of research in the field of social work. For some ethnographers there, narrative theory has provided an opening in which they can explore the social construction of meaning. ${ }^{14}$ Instead of the reportage of an apparently objective experience. In this type of ethnography, the interpretation of the subject's experience moves to the centre of the study. Gubrium and Holstein, for example, used narratives to explore the quality of life reality we have narratives which 
emphasise polyphony and the participants' own representations of their of nursing home residents. ${ }^{15}$ Instead of relying upon statistical analyses derived from questionnaires to determine quality of life for nursing home residents, they encouraged the residents to tell their own stories in their own words. They contrasted their methodology with that of other professionals in the field:

[t]he legal and mental health agents who participate in involuntary mental hospitalization hearings define and consider a candidate patient's dangerousness or so-called grave disability in terms of professional and organisational interests and agendas. ${ }^{16}$

The result was an enriched contextual study of the experience of recipients of care, one that added significantly to the body of more traditional, objectivist research

Versions of the above methodological approaches have been applied in the domain of law and, particularly in the last fifteen years, in the field of client counselling. Two distinct approaches are discernible in the field. First there are the student and practitioner texts on client counselling, those which advise upon and illustrate, according to the paradigm of skills and strategies, best practice in client counselling and ways to achieve this. ${ }^{17}$ Relying to a greater or lesser extent on research into skills development, these texts tend to focus more on generic behaviours which will enable students and trainees to become what some of the texts define as client-centred lawyers. Second, there is a substantial and growing body of research into the actual relationships between clients and lawyers. William Felstiner and Austin Sarat's influential analyses of lawyer-client relations were based on the first large-scale ethnographic survey of this field. Using 115 recorded interviews derived from forty divorce cases studied over thirty-three months, they observed the typical patterns of inter-relationships as these emerged. Thus, for example, commenting on the understanding which lawyers and their clients develop of each other's role, they observed -

[c]lients focus their interpretive energy in efforts to construct an explanation of the past and of their marriage's failure. Lawyers avoid responding to these interpretations because they do not consider that who did what to whom in the marriage is relevant to the legal task of dissolving it. In this domain clients largely talk past their lawyers, and interpretive activity proceeds without the generation and ratification of a shared understanding of reality. ${ }^{18}$

In Felstiner and Sarat's studies we can see the 'interpretive community' of lawyers, as Fish would define it, come under scrutiny from a variety of points of view. The investigation of client point of view via client narrative and interchange is one reason their research has been significant in the field, and has become valuable reading for those interested in client counselling education.

Where Felstiner and Sarat based their conclusions upon an ethnographic survey, others have written about their own experiences such as client disempowerment and silencing, the distortion of client narrative and the alienation of client experience. ${ }^{19}$ While a wide range of research techniques is employed by this body of research, and conclusions differ, what is remarkable is the extent to which it employs the tropes of narrative enquiry. One example will serve here. In one of his articles Clark D. Cunningham describes his methodology here and elsewhere as 'a Geertzian thick description, focusing on key words and offering possible explications of their broader and more complex meanings as constructions of social reality'. He acknowledged the influence of the German sociologist Beatrice Caesar-Wolf's study of the methods by 
which a judge "transformed lay testimony into "adjudicable evidence"' by transmuting "fragmented testimony into "a thematically coherent, sequentially presented story" [his emphasis]. To do this, "Caesar-Wolf subjected the transcript of the hearing to "extensive and exhaustive content analysis with regard to the ... largely latent meaning structures, which may not be necessarily intended by the parties involved"'. ${ }^{20}$ Cunningham's resumption of Caesar-Wolf's method, his description of his own, and the methodologies adopted by many other researchers in this field, show a sophisticated awareness of the potentialities of narrative theory to act as a criticism of legal discourse and practice.

Nor is this research oriented towards the courts and professional practice alone. Some of it deals with client counselling education in students' clinics, for example, or examines student response to clinical work. Most of the research has relevance for the teaching of client counselling and beyond. As Carrie Menkel-Meadows declared of the whole context of client counselling,

I believe that with a focus on empathy training through perspective-taking, roleplaying, simulation, and other forms of less conventional legal education, we can actually increase lawyers' awareness that they live in the world with other people who often have needs as legitimate or even more legitimate than those of lawyers or their clients. ${ }^{21}$

\section{Clinical Legal Skills Module}

At Glasgow Caledonian University students studying for a BA in Law with Administrative Studies are currently introduced to client counselling in the third year of their degree, in a module entitled Clinical Legal Skills. The module sets out to enable students to understand and apply in their work the basic principles of client counselling, legal writing and document drafting, negotiation skills, and - linking up with their fourth year Honours dissertation - advanced research skills. ${ }^{22}$

While students do to some extent practise personal transferable skills in other law modules, this module is different from most others the students study in that there is a strong personal element to the material they study, and in the activities in which they take part. This personal commitment to the module is emphasised, for much of the learning on this course involves students analysing the way they habitually respond to other people, and the ways they think about their selves and their self-presentations in society.

The module is divided into five separate units, four of which are the focus of class activity, with each unit taking up three weeks of class time. This is done so that, in a relatively unfamiliar learning environment, students may be able to focus more clearly on individual skill development. This goes against the grain of some clinical education theory, which holds that the most valuable learning takes place when students are flung in medias res, and where the learning ground and activity most closely approximates the situation of professional tasks. In this respect the linear path of the module would seem to contradict the polysemic quality of professional life where the practitioner often carries out multiple and quite different tasks involving different audiences and readerships. In part this impression is given by the student handbook, which sets out in detail the learning outcomes, forms of teaching and learning strategies, module reading and content, all of which conforms to a semester 
pattern. Nevertheless, in spite of the apparent linearity of the module, it is designed to be learned not sequentially but consequentially - one skill overlapping another - so that the module forms a unified whole. Some scenarios or role plays appear in different units, while the negotiation skills project is built upon work begun in the unit on client counselling and incorporates skills learned in legal writing and document drafting.

The module is assessed with a variety of instruments. Students are asked to complete a 1500 word self-appraisal report. ${ }^{23}$ They base this report on a learning log which they are issued with in the module handbook at the start of the module, and which they use during and after each session. Legal writing and document drafting is assessed by a three hour open book examination in which students can answer an (unseen) paper anywhere on campus. Negotiation skills are assessed in an email negotiation project based on the law of delict. The last unit, advanced legal research skills, is compulsory but unassessed. For their client counselling assessment students make at least two videotapes, choose their best performance and write a 1,000 word report on it. Students are assessed out of a total of $25 \%, 10 \%$ being allocated to the video and $15 \%$ to the report. The weighting, in favour of the report, is designed to encourage students to use the concepts of reflective practice: even if their best performance on tape is not particularly good, they can still pass the unit if they write an appraisal which is analytical and sensitive to the whole context of the experience, from the point of view of both the counsellor and the client.

The assessment of client counselling skills is an integral part of the learning process carried out in class. The class activities are structured around the same activities, which take place in broadly speaking the same order. After reviewing the previous session, we then either practise the day's role play, or else view excerpts from a video of a simulated role play, or a real solicitor-client interview. ${ }^{24}$ Following the interview, the class appraise the solicitor's interviewing skills, and take notes on this.

The students' role play is the central activity of the class. ${ }^{25}$ It involves an unseen scenario, normally lasting no more than half an hour and usually less, with other students playing the part of clients. The student counsellors work in pairs with their client(s); and once the client leaves, the counsellors spend five minutes or so, still on camera, discussing the case with each other. In this period they focus on their perception of the practical action necessary on completion of the interview (follow-up action, information contacts and the like); the professional aspects of the meeting (possible ways the case could go, likely success or failure of modes of action, conflict of interest, etc), and the affective elements generated by the interview - what were the client's feelings during the narrative and interview, what did they think of these, how did they feel they had handled the client, how could this have been improved, and so on. The class, client and counsellors then appraise the interview, with the counsellors leading this particular part of the class. This is emphasised as being the most important part of the whole session, both for the interview participants and the rest of the class. Finally, the class spend the last ten minutes or so completing their learning $\log$ for that session.

\section{The use of narrative strategies in the counselling class}


The main theoretical underpinning of the module is the work of Donald Schön. For Schön, professional artistry is a form of 'reflection-in-action', and it plays a central role in the description of professional capability. Because legal practice is an 'indeterminate zone of practice', the concept of the reflective practitioner is particularly relevant; and therefore reflective practice is one main aim of the module (Schön, 1988, p.6). ${ }^{26}$ Such reflection-in-action is a conscious construction and reconstruction of the world. In this sense, the indeterminacy of the zone is an analogy of the indeterminacy of the text discussed earlier. Schön pointed up the interpretive bases common to both domains -

when practitioners respond to the indeterminate zones of practice by holding a reflective conversation with the materials of their situations, they remake a part of their practice world and thereby reveal the usually tacit processes of worldmaking that underlie all of their practice. ${ }^{27}$

This underlying 'worldmaking' was made explicit to students in discussions of extracts from Schön's text, and others on the process of legal education. Rather than discuss legal practice, of which the students had little experience, we discussed reflection in the context of their experience of the degree programme to date, and alternative forms of legal education. ${ }^{28}$

The concepts of reflective practice, then, were made overt within class discussions, and were explicit aims and guided activities within the module. In contrast, the narrative heuristics were left deliberately floating in the module structure, though I knew they would be used at some point during the class. They were not therefore, from the students' point of view, a visible part of the superstructure of the module, nor were they intended to have been. As Julian Webb has pointed out, for all that the objectivist mode of aims and objectives is helpful in clarifying a class, syllabus or curriculum structure for a student, teaching is also a craft. Part of its artistry lies in the decisions of the teacher regarding where and when to deploy certain devices and debates; and this can often be decided upon only when both students and teacher are within the situation. ${ }^{29}$ If this is true of substantive law courses, it is even more true of clinical legal skills courses. There, legal learning is experiential and integrative. Much of the learning that goes on arises from the situation as it develops within and between the class and teacher, and instructional strategies should enable this learning to take place at variable rate, but in an organised way that provides a coherent structure for learning. The narrative strategies therefore remained - if we might adopt a software analogy - 'system-only files', and unseen by the end-user.

There is another reason why narrative techniques remained embedded within the structure of the system. To a high degree, as we have seen above, the concepts of narrative theory and its related topoi arise within another discipline, that of literary theory. If students were to use this theory in an overt way, or if they were presented with a teacher who used such theory, they would first have to come to an understanding of the theory. The classes would then have been laden with theory which students would then have had to transfer not only to legal learning within a clinical legal education class (itself a new experience), but to their own individual experience. This would have resulted in cognitive overload for students. ${ }^{30}$ It would also have resulted in the unnecessary isolation of theory from practice, and a classic instance of Schön's technical-rationality model of learning. 
The concepts of narrative theory were embedded within class discussion and role play, therefore, and it was a rule of play never to introduce a concept unless there was first an example from a student's work - writing or role play - which gave rise to cognitive dissonance within the class. When there is such dissonance, and an uncertainty as to how to proceed, then students are receptive to new ideas. Sometimes they arrived at these ideas themselves, and it remained for me to highlight the innovatory nature of their solutions to the problem.

There is a difficulty associated with this approach, of course - that of the 'hidden curriculum' within a class. As defined by Sockett this can apply to three of the negotiated areas between teacher and learner within a curriculum: the lore received by students about a class from other students; what students actually learn, as opposed to what their teachers may assume they are learning; and the hidden agendas of teachers. ${ }^{31}$ The last occurs when a teacher's attitude to a certain knowledge base remains unclear or hidden from students, who then are put in the position of having to second-guess the teacher's preferences. This role only reinforces the passive role that students may play within a class. In a clinical legal skills class it contributes little to the self-development of students.

There is, however, a key distinction between the embedded use of narrative techniques, and the deficiencies of the hidden curriculum. In the latter, students are often working within the 'teaching as telling' theory of learning, and seeking to discover preferences in order to replicate them, very often so as to obtain good assessment grades. ${ }^{32}$ In Clinical Legal Skills, however, students were presented with tools and concepts, a way of seeing, which they were encouraged to use. By using narrative techniques students became apprentices: the rhetorical category of imitatio is one model of this. Donald Schön's concept of imitation is another:

...Follow me! tends often to evoke negative reactions in coach and student alike, whenever it becomes explicit. Yet imitation is essential to learning, just insofar as students are initially unaware of what they need to learn, and it can be a creative act of considerable complexity.

Paradoxically, it is blind imitation, rather than imitation as such, that most threatens a student's autonomy; and it is blind imitation that students and coaches encourage when they keep imitation tacit. In order to encourage reflective imitation, coaches may need to invite students to reflect on their negative attitudes toward imitation. ${ }^{33}$

Most of the module was composed of workshops where students could carry out the procedural skills involved in putting reader-response and point-of-view into practice. Students readily grasped the general principle - that reader-response and point of view is crucial to effective lawyering - but found it much harder to practise it. In the legal writing unit, for example, most of the activities were aimed at sensitising students to their audience's needs, awareness, textual expectations and levels of comprehension. Part of the problem here is that students at university generate most of their text for a highly artificial audience, namely tutors, whose knowledge of the subject domain is greater than the students. As a result of this and other factors, students tend to focus largely on textual content and pay little attention to reader response or expectation. In legal practice, the situation is often the reverse: trainees find they are writing (and 
speaking) to a wide variety of audience response and expectations, and they require to learn sensitivity to the complexities of reader-response.

To enable students to learn this, writing activities were designed to call up readerresponse in the writer, so that students wrote letters and memos which were readercentred rather than writer-centred. Several criteria were used. The activities were always designed so that either audience needs were well-defined, or else were illdefined and required definition by the students. The concept of safe and dangerous readers was also introduced: students discussed what constituted a misreading of a text then discussed situations in which readers can misread dangerously and for what ends. Reader-motivation was also introduced, and all this was practised in activities where students had to write memos and letters to specific audiences with specific requirements. ${ }^{34}$ Students also learned what level of detail is appropriate in a text - that is to say, what information may be given and what remain unwritten. In these activities they learned to place and control textual detail, and to create their own indeterminacy in a text. ${ }^{35}$ Thus the level of detail required in a pursuer's letter to a defender intimating a delictual claim would be substantially less than the density of detail in letters further down the chain of correspondence. Many students found that these workshops improved their writing. One wrote in her self-appraisal report:

I normally do not even consider the audience to whom my essay is addressed. By analysing other legal essays I found I could think more about how I should structure a legal argument to make it more effective.

Audience sensitivity and point of view were key themes in the client counselling module too, and most of the workshops gave students practice in developing such sensitivity. Little in students' previous classes prepared them for this. In their adjectival and substantive law classes they did not face living clients who told narratives where fact and law appears irremediably confused. Much of their time was spent reading and learning from legal texts, from which the original client narrative that gave rise to the case law has long since disappeared. In place of the client narrative was an eloquent flow of legal description and analysis which aimed to provide a neutral, objective and privileged view of events. As Kim Lane Scheppele remarked of this voice, its "very "point-of-viewlessness" gives it its power'. ${ }^{36}$ This point-of-viewlessness, as Scheppele observes, is typical of an objectivist theory of truth, a theory which holds that it is possible to give a version of events that really happened, as opposed to the variants of what happened given by different parties. This theory, of course, is opposed by most legal narrative theorists, for whom point of view, stance, and the rhetorical nature of truth are crucial components in legal practice.

They are also the components which cause students real perplexity. In their discussions of videotapes students often revealed how uncertain they were about dealing with point of view. The following excerpt from an interview between solicitor and client on the subject of divorce, viewed by students during a workshop and then discussed by them, gives an example of their difficulties, and the solutions that narrative techniques can provide: 
solicitor .....The defences then, didn't table...that was your wife's fault, your wife's solicitor's fault. We can force tabling if you want...or we can leave it lying...

client What d'you mean? I'm not quite sure what you mean.

solicitor It's just a technical - it's a technical hearing and it allows us to put our defences in, it allows us to respond to the writ, what your wife said. We haven't been able to do that because of a failure on your wife's solicitor's part.

client Right. What I wanted to see you about anyway was...eh....she's divorcing me, correct?

solicitor Mm.

client I don't want her to divorce me. I want to divorce her because she was the one to blame.

solicitor Right, OK.

client You're saying it doesn't matter, but it matters to me because she's going to say things that are just not on, you know. She has no grounds for divorce, I have.

solicitor I will deny them. I realise that. I know your position as far as your wife's concerned, I know that sometimes she's maybe not very coherent, she's ill, I think, isn't she?

client Uhu, she is ill.

solicitor It's just expensive.

client I know, but at the same time I don't want her getting a divorce on her grounds -

solicitor Yes.

client - and my behaviour, it's just not on.

solicitor Well, we can defend the divorce, although I'm not very happy, I don't normally give that advice to people. I think you're wasting your money, you've got to look -

client How's it going to look, she gets the divorce because of what she says about me?

solicitor Right.

client That's destroying my character, it's just not on.

solicitor No, it's not a character assassination, it's a bit of paper you get at the end of the divorce, and I'm sure I've said this to you, it says that the pursuer is granted decree of divorce from the defender, that's all it says. It doesn't go into whether you've been a bad guy and whether she's been wronged or....there's no blame attached.

client But then it's going to go down as that, surely? She's going to get a divorce. She gets the divorce.

solicitor Mm, you both get a divorce.

client Ah but, who's actually, who's to blame?

solicitor It doesn't matter.

client Why?

solicitor It just doesn't.....

client Surely if it says that....she's going to say anyway that I've been a bad guy to her for the last six or seven years and the judge is going to look at this and say, "He is a bastard", right?

solicitor Right. 
client "So, I'm going to sort him out when it comes to a settlement", and it's just not on.

solicitor No, right, OK, I see what you're getting at now. It does not affect

financial settlement in divorce. It doesn't have any influence on the way the judge decides where the money goes. There's a no-blame system of divorce in Scotland and it will not make any difference to the sum that she gets, if she gets anything. It's as simple as that.

client You see I have good grounds for divorce.

solicitor I know that, most people have usually, both sides have usually good grounds....

client Aha, I have, she hasn't.

solicitor Yes. I can defend the divorce, OK?

client Uhu.

solicitor It's a waste of money. You want to get divorced from your wife, why not let her divorce you? The marriage has broken down, hasn't it?

client And what's going to happen in court, when she turns round to me...turns round and says that my behaviour has been contributory to our divorce, that means I have to accept that?

solicitor There will be no hearing on it, there'll be no hearing on the evidence of the breakdown of the marriage, so you won't have to go through that.

client No, but she's going to state this, I mean somebody's going to read that, surely.

solicitor Yes, they'll put it in affidavits. It doesn't affect the financial settlement.

client As far as I'm concerned there shouldn't be one anyway, you - she's the one that walked out, she's the one that's committed adultery, she is the one that...her mother does not want to know, her brother does not want to know, her daughter does not want to know. She phoned her daughter last week and X's told her she did not want to speak to her at all.

solicitor Right, right. Well, I'll put it in practical terms then. If we defend the divorce and we raise our own action -

client Right.

solicitor - the cost will cost you another $£ 2000$. That's it in practical terms and we'll get the same outcome, only we'll be $£ 2000$ poorer off for it.

client Right. It's not going to cost me any more the other way? Is she going to get....see, the likes of my position just now, I mean the house is in my name, is she going to have claim on that?

This dialogue raises a number of perplexing issues for students. On a fairly overt level there is the issue of legal jargon ('tabling'), of how to explain legal process to clients, and how to advise on the law correctly. But there is a subtext to this difficult dialogue: the lawyer wants one method of achieving the outcome of divorce, the client another. For the client, the method of divorce is crucial, and his concern for this rests upon a moral economy which is based upon culpa. In his view his wife is morally culpable for the breakdown of the marriage, and he adduces in support of this the views of his interpretive community, the family group. His perception of the case is thus significantly different from that of his solicitor.

On the solicitor's part there is an implicit searching for motive as to why the client wants to defend the divorce. The lawyer eventually attributes it to anxiety about financial penalty ('OK, I see what you're getting at now'...); but the client, as the rest 
of the excerpt and the interview shows, is concerned primarily about the morality of the divorce process, not only the financial losses he may incur. There is a dichotomy here between the lawyer's teleological and pragmatic view of the law and his role as agent or hired gun, and the client's sense that justice has been denied him - a sense that leads him to insist on putting in defences to a divorce he actually desires. What is happening here corresponds exactly to Felstiner and Sarat's description of clients talking past their lawyers, and where 'interpretive activity proceeds without the generation and ratification of a shared understanding of reality' (quoted above). Through discussion of this 'interpretive activity', students began to come to an understanding of the importance of point of view and the motives underlying it: the lawyer's, the client's, their own in learning, mine as their tutor.

Students' understanding of these issues was affected by the medium of the narrative, to the extent that there were significant differences between their reading of the above dialogue as text and as video dialogue. Students were asked to read the text before coming to the class; and in discussion of the interview structure before they viewed the videotape, a number commented that the client seemed to dominate the interview. They were right of course: the interview is client-led, and this gave rise to an interesting discussion about dialogue structure and how, from their reading of the text, the students could discern this domination when on the face of it, the dialogue seems to be evenly distributed between lawyer and client. But they also commented after they had seen the tape that their point about client domination would not have been so apparent from viewing the videotape alone. This may have been a function of the fixed camera position, where for reasons of confidentiality only the lawyer appeared in the frame; or it may have been that the visual presentation of the conflict between lawyer and client made structural analysis of the dialogue more difficult to discern. It is clear, though, that using dialogue as textual narrative has advantages for microanalysis of, and self-presentation within, language, that use of video dialogue does not easily accommodate. Students began to discern the meta-narratives, the "largely latent meaning structures"' which Caesar-Wolf described above (p.6). And vice versa, of course: as videotaped dialogue, the narrative was transformed and presented students with physical and aural presences, as well as the affective interaction between lawyer and client, which textual narrative cannot convey so well.

I have shown this video clip to a number of student groups, and more often than not they are affected and troubled by the dissonance between lawyer and client. What helps them to understand the structure of the interview, and the moral basis of the two positions is an awareness of reader-response and point of view - the lawyer's, the client's, and their own. As we shall see, this was borne out by student comment in the self-appraisal reports.

\section{Recipes}

If the two narrative devices helped students to analyse others' tapes and scripts as well as their own, they also enabled them to develop reflection-in-practice. One such practical application was the use of 'recipes'. As Robert Putnam defined them, these are 'sentence fragment[s] with a characteristic wording that can be used to design interventions for some class of situations'. The idea of 'recipes' is in one respect a modern version of the ancient link between rhetoric and mnemonics; but set within the cognitive framework of Schön's reflection theory. Recipes are one way for 
learners to move from what Schön identifies as Model I theory of action (where four values are dominant: rationality, winning, suppressing negative feelings, achieving personal goals) to a Model II theory of action (where values of free but informed choice, internal commitment and valid information are the dominant values). Most people acknowledge the importance of Model II values but have difficulty in enacting them. ${ }^{37}$ Recipes are one way to achieve the shift from one model to another, and to embed reflective learning within the practice situation. ${ }^{38}$

As always with Schön's ideas, the process by which students came to an understanding of practice is critical. When this heuristic was used with a class the previous year, I asked students to read Putnam's article, then come to the class prepared to work with the idea. The subsequent class was not successful: students arrived complaining that the article was theory-laden, that they didn't see its relevance to law, and that they could not see what they were supposed to put into practice. They were right to complain. In the middle of a reflection-based module they were being asked to learn according to a version of technical-rationality education, as Schön termed it - not so much reflection in or on action as reflection before action. The next year the module ran, I removed Putnam's article from the class reading, made no mention of it in advance of the workshop where I introduced the idea, and introduced the idea in discussion of a student's video. The idea was instantly adopted by other students as useful and one which each of them could adapt to their own versions of artistry. In the middle of a role play which was developing much like the excerpt above, for example, one student recognised the value of the phrase, "why do you want me to do this for you?'. Out of the subsequent class discussion arose a number of the points that Putnam raises in his article concerning the advantages of recipes (they are memorable; can act creatively to shift or reframe a dialogue); and their dangers (they can be used mechanically; they can be a form of 'covert advocacy', inducing 'defensiveness and polarisation'). ${ }^{39}$

\section{Conclusion}

In this module students were given a three-week introduction to client counselling, one which, by using narrative theory and reflection theory, they began to learn the practice of counselling, and began to integrate this experience with other activities that lawyers carry out in practice, such as writing and negotiation. Most students found the use of narrative devices helpful in understanding the dynamics of client counselling, and in integrating interviewing with writing. With reference to recipes, for instance, three students commented (and their comments are representative of the class response) -

The first point I learned in Clinical Legal Skills was that I tend to over-react before I actually know what lies ahead ... I became a more responsive client counsellor ... I also developed the use of recipes to enable me to structure interviews effectively.

One aspect in which I felt I failed to grasp the full potential was the use of recipes - if the client makes a mention of something relevant then it's important that the interviewer should be aware of what questions he or she should be asking in relation to that subject. 
At no point [in the interview] did I have a proper recipe in my head. I should have concentrated on this, rather than expecting this just to happen without any (real) effort.

One student made the following acute distinction between learning from others and learning in her own experience which showed that, even if the unit had not entirely succeeded for her, the concepts of reflection in and on practice had probably given her greater insight into why this was so.

I was amazed just how much I was able to learn just by watching other students' role plays and seeing where they were going wrong or what good points I could learn from them, and I feel it is important to emphasise that practice was essential. You became better at handling situations with experience. One thing I would say about this unit is that although I became better at realising what I was doing wrong, I don't feel that my actual performance improved.

Another summed up how she had managed to embed the experience of the course in a situation outside the class, demonstrating impressive transference of learning:

Once the unit was over, I was made aware of how useful counselling techniques can be. An aunt of mine had received a letter from her old employers regarding her widow's pension. Many of the material details were inaccurate [examples cited]. I was asked to draft a letter to her employers. When discussing this with my aunt I found myself making very effective use of counselling skills and managed to gather several details which, although my aunt did not think them important, I thought them relevant. This made me realise how much I had learned and how useful the unit had been for me.

With more time, it would have been possible to have carried out more detailed analysis of the process of interviewing. Students could, for example, begin to understand how to perform linguistic analysis of text and how to carry out an ethnomethodological analysis of interview scripts and tapes. ${ }^{40}$ The use of turn-taking in conversation, of silence, interpolation, voice inflection, genderlect and much else that is the subject of linguistic discourse analysis could be shown to students as a subject of legal research, and one which they could validly undertake should they wish to do so. ${ }^{41}$ In the future, some of this material will be included in a 'Narrative and Law' option contained in the Jurisprudence course, also a third level module.

\footnotetext{
${ }^{1}$ Senior Lecturer in Law, Dept of Law \& Public Administration, Glasgow Caledonian University. Thanks to Amanda Millar and Patricia McKellar (co-tutors on the client counselling unit) for their valuable advice; and to Stephen Doogan, research officer.

${ }^{2}$ W.J.T. Mitchell, On Narrative. Chicago University Press, Chicago, 1981, ix.

${ }^{3}$ In this second stream, most researchers have demonstrated an interest in what Richard Delgado once described as narrative's 'counterhegemonic' power. Delgado, letter to Kevin Kennedy, June 1 1988, quoted in Kim Lane Scheppele, 'Foreword: Telling Stories', 87 Michigan Law Review (August 1989) 2075

${ }^{4}$ Ibid.

${ }^{5}$ The activities of the class centred on the category of legal interviews where a member of the public seeks advice from a legal practitioner. Consequently, I chose to use the phrase 'client counselling' rather than 'interview skills' as being more descriptive of the contents of the class. Albeit the phrase is American and therefore stems from a different cultural context, it goes to the heart of the aims of the class, with its emphases on the client and on the counselling context of legal advice-giving.
} 
${ }^{6}$ Jane P. Tompkins, Reader-Response Criticism: From Formalism to Post-Structuralism. The Johns Hopkins University Press, Baltimore \& London, 1980, 55

${ }^{7}$ Ibid, 59

${ }^{8}$ Ibid, 62

${ }^{9}$ Ian Reid, Narrative Exchanges. Routledge, London, 1992, 23, discussing Shlomith Rimmon-Kenan's Narrative Fiction: Contemporary Poetics. Methuen, London, 1983

${ }^{10}$ Doing What Comes Naturally: Change, Rhetoric and the Practice of Theory in Literary and Legal Studies. Clarendon Press, Oxford, 1989, 153. This concept is crucial to Fish's analyses of legal issues and texts. In his analysis of Dworkin's view of textual interpretation, for example, Fish agrees with Gerald Postema's substitution of a world of practice for Dworkin's rule of integrity: “" $[\mathrm{t}] \mathrm{o}$ learn a social practice ... is to become acquainted through participation with a new common world; it is to enter a world already constituted"'; and Fish goes on to quote further from Postema - "'through participations one comes to grasp, tentatively and uncertainly at first, then more securely, then critically, the common meaning of practice"' (Ibid, 580, note 3)

${ }^{11}$ Op cit, 12. In his essay 'Force' in this collection Fish works out the consequences of this argument in relation to H.L.A. Hart's internal and external 'points of view' with regard to the imperatives of a legal system (ibid, 520-21).

${ }^{12}$ L.S. Schulman, 'Knowledge and Teaching: Foundations of the New Reform', 57 Harvard Educational Review (1987) 1; R. Coles, The Call of Stories: Teaching and the Moral Imagination, Boston, Mass., Houghton Mifflin, 1989; H. Munby, 'Metaphor in the Thinking of Teachers: An Exploratory Study', 18 Journal of Curriculum Studies (1986) 197; W.A. Reid, 'Institutions and Practices: Professional Education Reports and the Language of Reform', 17 Educational Researcher (1988), 10

${ }^{13}$ E.F. Elbaz, Teacher Training: A Study of Practical Knowledge. Croom Helm, London, 1983. F.M. Connolly \& D.J. Clandinin have been prolific in this field. Amongst their key publications are 'Stories of Experience and Narrative Enquiry', 19 Educational Researcher (1990) 2; 'On Narrative Method, Personal Philosophy and Narrative Unities in the Story of Teaching', 23 Journal of Research in Science Teaching (1986) 293; 'Narrative and Story in Practice and Research' in Donald Schön, editor, The Reflective Turn: Case Studies of Reflective Practice. Teachers' College, New York, 1991; 'Rhythms in Teaching: the Narrative Study of Teachers' Personal Knowledge of Classrooms', 2 Teaching and Teacher Education (1986) 377

${ }^{14}$ See B. Cohler, 'Ageing, Morale and Meaning: The Nexus of Narrative' in T.R. Cole, W.A. Achenbaum, P.L. Jakobi, R. Kastenbaum, editors, Voices and Visions of Ageing. Springer, New York, 1993, 107-33. See also Clifford Geertz, Works and Lives. Stanford, Stanford UP, California, 1988 ${ }^{15}$ J.F. Gubrium, Speaking of Life: Horizons of Meaning for Nursing Home Residents. Aldine, Hawthorne, NY. The terminological similarity to Jauss' metaphor of the 'horizon' is perhaps coincidence; but highlights the common origin of both lines of research within the field of phenomenology where this metaphor is used.

${ }^{16}$ J. F. Gubrium, James A. Holstein, 'Biographical Work and New Ethnography', Interpreting Experience: The Narrative Study of Lives, vol.3, Ruthellen Josselson \& Amia Lieblich, editors. Sage Publications, Thousand Oaks, California, 1995, 47

${ }^{17}$ See for example, Binder et al, Lawyers as Counselors: A Client-Centered Approach 1991. Avrom Sherr, Client Interviewing for Lawyers. Sweet and Maxwell, second edition, 1996. Lawrence Shurman, The Practical Skills of the Solicitor. Longman Professional Series, second edition, 1985. Helena Twist, Effective Interviewing. Legal Practice Handbook Series, Blackstone, 1993. James Alexander, Client Care Blackstone Press, London, 1993

${ }^{18}$ William L.F. Felstiner \& Austin Sarat, 'Law and Social Relations: Vocabularies of Motive in Lawyer/Client Interaction', 22 Law and Society Review (1988) 742. See also Bryna Bogoch, 'Power, Distance and Solidarity: Models of Professional-Client Interaction in an Israeli Legal Aid Setting', 5 Discourse and Society (1994) 65; Bryna Bogoch \& Brenda Danet, 'Challenge and Control in LawyerClient Interaction: A Case Study in an Israeli Legal Aid Office', 4 Text (1984) 249

${ }^{19}$ This category of research is considerable. Representative texts include : A. Alfieri, 'The Politics of Clinical Knowledge', 35 New York Law School Review (1990) 7; Robert Dinerstein, 'Client-Centered Counseling: Reappraisal and Refinement', 32 Arizona Law Review (1990) 501; Creighton Law Review, vol 18 no 5, 1984-5, special issue on legal counselling; Clark D. Cunningham, 'The Lawyer as Translator, Representation as Text: Towards an Ethnography of Legal Discourse', 77 Cornell Law Review (1992) 1298; William L.F. Felstiner \& Austin Sarat, 'Enactments of Power: Negotiating Reality and Responsibility in Lawyer-Client Interaction', 77 Cornell Law Review (1992) 1447; Ibid, 'Law and Social Relations: Vocabularies of Motive in Lawyer/Client Interaction', 22 Law and Society 
Review (1988) 737; Phyllis Goldfarb, 'The Theory-Practice Spiral: Insights from Feminism and Clinical Education', 75 Minnesota Law Review (1991) 1599; Clark D. Cunningham, 'A Tale of Two Clients: Thinking About Law as Language', 87 Michigan Law Review (1989) 2549; Peter Margulies, "Who Are You to Tell Me That?": Attorney-Client Deliberation Regarding Non-legal Issues and the Interests of Nonclients', 68 N.C. Law Review (1990) 213; Julian Webb \& Caroline Maughan, 'Taking Reflection Seriously: How Was It for Us?’ Teaching Lawyers' Skills, edited by Julian Webb \& Caroline Maughan, Butterworths, London, 1996, 261-291; Phillip Jones, 'We're All Reflective Practitioners Now: Reflections on Professional Education', ibid, 291-323; Gerald Lopez, 'The Work We Know So Little About', 42 Stanford Law Review (1989) 1

${ }^{20}$ Op cit, $1352-3$

21 'Is Altruism Possible in Lawyering?', Ga. St. University Law Review 8 (1992), 385, quoted in Richard Delgado, 'Rodrigo's Eleventh Chronicle: Empathy and False Empathy', 84 California Law Review, (1996) 90 at note 136.

${ }^{22}$ The year group consists of approximately 50 students divided into two groups of around 25 students. Class time consisted of two two-hourly workshops per group. The numbers in the client counselling groups were further halved by the introduction of another lecturer: in the first year of the module's running, Amanda Millar, in its second year, Patricia McKellar, who will be co-teaching this year's module too.

${ }^{23}$ Most students were anxious about this assessment, having never written anything like it before. The daily learning logs, though, reduced this anxiety. By the end of the module most students were of the same opinion as one who commented, 'the self-appraisal report I feel is a very good idea because it has forced me to reflect on the whole module and in particular each unit which in turn has helped me to make sense of everything in the module.'

${ }^{24}$ This interview was videotaped with the permission of solicitor and client. All necessary steps were taken to preserve client anonymity, including a fixed camera position focusing only on the solicitor.

${ }^{25}$ Students could also choose to conduct interviews in private, out of class time. For many, this provided valuable practice.

${ }^{26}$ Donald Schön, Educating the Reflective Practitioner, Jossey-Bass, San Francisco, 1987. 6

${ }^{27}$ Ibid, p.36. Schön's ideas are now widely influential. For a description of their relevance to legal education, see Marlene Le Brun and Richard Johnstone, The Quiet (R)evolution: Improving Student Learning in Law, The Law Book Company, New South Wales, 1994, 27-8; Phillip Jones, 'We're All Reflective Practitioners Now: Reflections on Professional Education', in Teaching Lawyers' Skills, op cit, 291. Jones gives a useful critique of Schön at 315-21

${ }^{28}$ These texts included Andrew J. Pirie, 'Objectives in Legal Education: The Case for Systematic Instructional Design', 37 Journal of Legal Education (1987) 576; Julie MacFarlane, 'Look Before You Leap: Knowledge and Learning in Legal Studies Education’ 19 Journal of Law and Society (1992) 303; Robert Benson, 'The End of Legalese: The Game is Over', 13 New York University Review of Law and Social Change (1984), 531, reprinted in George D. Copen, 'The State of Legal Writing: Res Ipsa Loquitur', 86 Michigan Law Review (1987), 333; Paul J. Spiegelman, 'Integrating Doctrine, Theory and Practice in the Law School Curriculum: The Logic of Jake's Ladder in the Context of Amy's Web', 38 Journal of Legal Education (1988) 243. One student commented in her self-appraisal report that, by the end of the module, she had 'come to realise the importance of self-reflection, as it has made me think long and hard about a course, something I have never done before.'

29 'Where the Action is: Developing Artistry in Legal Education', 2 International Journal of the Legal Profession (1995) 187

${ }^{30}$ The problem of dealing with theory and solutions to it are discussed in 'Taking Reflection Seriously: How was it for Us?' in Teaching Lawyers' Skills, op cit, 275-81. It is interesting that Webb and Maughan make reflection theory explicit within a simulated legal practice, as opposed to a legal educational, activity. They note that the activity helped students 'discover how their reflective processes worked to enable them to learn' (p.281). I had not read their book before planning my own approach.

${ }^{31}$ B. Sockett, Designing the Curriculum. Open Books, London, 1976

${ }^{32}$ This theory of learning cited in P. Ramsden, Learning to Teach in Higher Education. Routledge, London and New York, 1992, 112

${ }^{33}$ Op cit, 293

${ }^{34}$ Students also practised this in their academic assignments. As one student commented with regard to paragraph structuring: 'this was extremely rewarding, for that week I used [the techniques practised by] our group in an essay for European Legal Studies, where I attained my highest mark for an essay in university'. 
${ }^{35}$ And in the course of the activity they learned the difference between indeterminacy and ambiguity...

36 'Foreword: Telling Stories', op cit, 2089, quoting Catharine MacKinnon, 'Feminism, Marxism, method, and the State: Toward Feminist Jurisprudence' 8 Signs (1983) 635 at 638-9

${ }^{37}$ See C. Argyris, Reasoning, Learning and Action. Jossey-Bass, San Francisco, 1982

${ }^{38}$ Robert W. Putnam, 'Recipes and Reflective Learning: "What Would Prevent You From Saying It That Way?", The Reflective Turn: Case Studies in and on Educational Practice. Donald Schön, editor, Columbia University Press, New York, 1991, 147

${ }^{39}$ Ibid, 147

${ }^{40}$ As Clark D. Cunningham describes it, ethnomethodology involves applying the 'techniques of descriptive linguistics to speech events such as conversations or group decisionmaking which are more complex than single utterances on the assumption that the social categories that produce and manage such interactions are in essence semantic categories'. 'The Lawyer as Translator, Representation as Text: Towards an Ethnography of Legal Discourse', op cit, 1345. As Cunningham points out, ethnomethodology is distinct from ethnography in that it takes the researcher's own society as part of the subject of study: 'all the material studied is treated from the outset as "anthropologically strange"" (ibid. 1345)

${ }^{41}$ Much of this research in the legal field began as analysis of court discourse. See for example Harry Garfinkel, Studies of Ethnomethodology Prentice-Hall, Englewood Cliffs, NJ, 1966; 'The Origins of the Term "Ethnomethodology"' in Ethnomethodology: Selected Readings. Roy Turner, editor, Peguin Education, Harmondsworth, 1974; J. Maxwell Atkinson \& Paul Drew, Order in Court: the Organisation of Verbal Interaction in Judicial Settings. SSRC, Macmillan, London, 1979. Deborah Tannen, You Just Don't Understand: Women and Men in Conversation (1990) 